\title{
Gaining a competitive advantage through strategic human resource management in Indonesian construction industry
}

\author{
Winda Widyanty ${ }^{a^{*}}$, Apollo Daito ${ }^{a}$, Setyo Riyanto ${ }^{a}$ and Dewi Nusraningruma
}

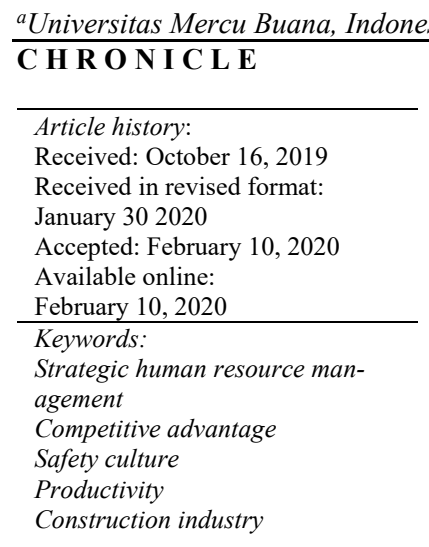

\section{A B S T R A C T}

This research was conducted to test the model of strategic human resource management as a competitive advantage in the construction industry specially to identify factors related to achieving competitive advantage in this industry. The empirical data were drawn from 174 construction companies in Indonesia using questionnaire method. Structural Equation Modeling techniques was used to analyze the conceptualized relationship model. The empirical results reveal that competitive advantage in the construction industry in Indonesia could be achieved through human resource management practices to build and improve a safety culture which would increase employee productivity. Companies must integrate human resource management practices with safety culture as a priority strategy of the company since based on empirical result, safety culture can be a source of competitive advantage for construction companies in Indonesia. Future studies can use these strategic human resource management models in different industry sectors by adding a number of samples so that the results could be generalized.

\section{Introduction}

In the world of global competition, competitive advantage is an important challenge for all companies to have. That is because the growth and success of a company is determined by the presence or absence of a competitive advantage which is owned compared with competitors in the same industry. Also, competitive advantage in companies indirectly provides an important role in the position of a country. This is due to the success of competitiveness in shaping local competition and creating products that are the main determinant of a country's economic growth and prosperity. The World Economic Forum (WEF, 2017) recorded an increase in Indonesia's competitiveness from position 38 in 2016 to position 34 in 2017. The increase in competitiveness is the impact of a large increase in market size in the construction sector as a result of infrastructure development in Indonesia and the environment relatively strong macro-economic. However, Indonesia's competitive position is still far compared to other ASEAN countries. This can be seen in Fig. 1. Becker et al. (1997) explained that the company's competitive advantage can be achieved through human resource management practices that support the development of employee skills and motivation. This results in increased productivity and creativity which would affect performance improvement. Furthermore, previous research states that work safety culture and employee health problems must be prioritized due to increased awareness of employee welfare at work (Clarke, 1999). Employees who experience potential threats will face a series of physiological, psychological and emotional problems, which ultimately affect organizational performance (Zacharatos et al., 2005). Therefore, it is very important to integrate various aspects of human resource management practices in developing an understanding of how perceptions about workplace safety culture synergistically affect company performance as a competitive advantage of a company (Delery \& Doty, 1996). This study tries to offer preliminary evidence on human resource management strategies to form a work safety culture that increases employee productivity as a competitive advantage for companies. 


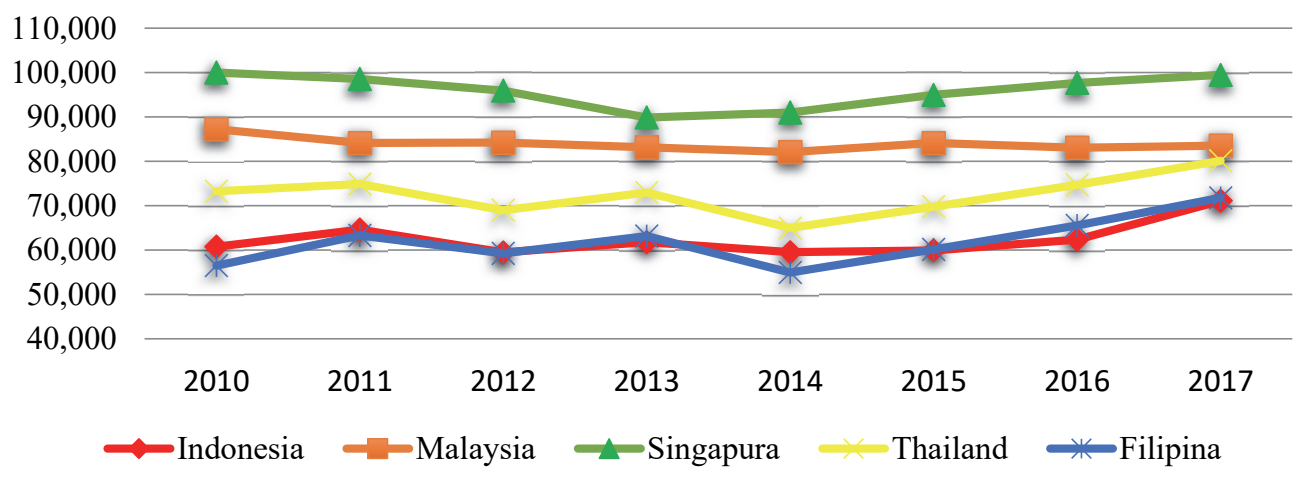

Source: World Competitiveness Index (2017)

Fig. 1. Indonesia's competitiveness ranking of the five ASEAN countries 2010-2017

To overcome the gap of problems that occur and gaps in the current literature, this study aims to study the competitive advantage of construction companies in Indonesia. This research explores the relationship between human resource management practices with other latent variables that influence the competitive advantage of construction companies through the Structural Equation Model (SEM).

\section{Literature Study and Hypothesis Development}

Currently, Resource-Based View (RBV) is considered as one of the most widely accepted theories related to the creation of competitive advantage by companies and industries such as works created by Barney (1991) with related concepts. Some empirical research shows that the effect of the RBV perspective shows a higher significance than the influence of industry on performance as in the Five Force of Porter Framework as research.

\subsection{Competitive Advantage}

Barney (1991) explains that the resources in a company are declared valuable when these resources can be used to implement strategies that can produce effectiveness and efficiency. Resources are said to be scarce if these resources are not owned by other companies, especially competitors. With these resources, the company can implement strategies that competitors will not be able to do the same thing, because they do not have the resources to implement these strategies. In addition to being valuable, scarce, and difficult to replicate, resources that produce sustainable competitive advantage must also have characteristics that have no substitute. This means that competitors do not have equivalent resources as a substitute for implementing their strategy. Even though the company has valuable, unique and difficult to imitate resources, if competitors have equivalent substitutes, then those resources will no longer be a source of sustainable competitive advantage. This is explained in Fig. 2 below:

\begin{tabular}{|c|c|c|}
\hline Resources & Competitive Advantage & Performance \\
\hline $\begin{array}{l}\text { Resource/ Capabili- } \\
\qquad \text { ties: } \\
\text { - Valuable } \\
\text { - Rareness } \\
\text { - Inimitable } \\
\text { - Non-Substitutable }\end{array}$ & $\begin{array}{l}\text { Competitive Implication: } \\
\text { - } \quad \text { Competitive disadvantage } \\
\text { - } \quad \text { Competitive parity } \\
\text { - } \quad \text { Temporary competitive ad- } \\
\quad \text { vantage } \\
\text { - } \quad \text { Sustained competitive ad- } \\
\text { vantage }\end{array}$ & $\begin{array}{cc}\text { Economic Performance: } \\
\begin{array}{cc}\text { - } & \text { Below Normal } \\
- & \text { Normal } \\
- & \text { Normal Above } \\
\text { - } & \text { Above Normal }\end{array}\end{array}$ \\
\hline
\end{tabular}

Fig. 2. Linkage Resource with Competitive Advantage

Source: Barney, 1991

The framework was first introduced by Barney in his book on Gaining and Sustaining Competitive Advantage (Barney, 1997) which revealed four key parameters for a company's resource-based analysis to create a competitive advantage. Barney states that strong resources must have the following attributes: (1) must be valuable; (2) must be rare; (3) must not be easily imitated; and (4) it is not easy to find a replacement. 
Referring to the perspective of Resource-Based View (RBV), human resource management practices are defined as a set of practices of corporate strategy designed to attract, develop, motivate, and retain employees in order to carry out functions in achieving the company's objectives to meet requirements as a source of excellence compete for the company. Over the past twenty years, the idea of human resource management practices (HRM) has received much attention. The researchers propose that some HRM practices have significant impacts on organizational performance. For example, HRM practices were found to positively influence turnover (Guthrie \& Datta, 2004; Huselid, 1995), work productivity (Huselid, 1995), company productivity (Guthrie \& Datta, 2004) and strong financial performance (Guthrie \& Datta, 2004; Huselid, 1995). These findings support that a specific set of HRM practices can be a potential source of competitive advantage (Becker \& Huselid, 1998). Among the arguments in this relationship, most experts take a resource-based view from a strategic perspective and argue that employees as human capital can be a source of competitive advantage when they add value to the organization (Delery \& Shaw, 2001; Huselid, 1995). Given the difficulty of imitating them, these human resources uniquely contribute to the success of the organization. From this view, ongoing investment in human capital that is specific to a company can distinguish company employees from others through enhanced knowledge, abilities, skills, commitment, thereby reducing the possibility of imitation (Huselid, 1995).

Also, multidimensional human resource management practices are believed to influence the shape work safety culture in companies (Chuang, 2013). Work safety culture which is a perception of various aspects of safety in the work environment can only function if human resource management practices are carried out following company strategies that have a high commitment to work safety (Rui et al., 2017; Handoko et al., 2015). Furthermore, Ployhart et al. (2011) theorize that human resource management practices such as training creating knowledge and skills improve the ability of the workforce which in turn will increase their productivity. Furthermore, Guzzo et al. (1985) meta-analysis showed that recruitment, selection, training, and performance appraisal had significant and positive effects on productivity. Thus, the following hypothesis is proposed in this study:

$\mathbf{H}_{1}$ : Human resource management practices affect Safety Culture.

H2: Human resource management practices affect Productivity.

$\mathbf{H}_{3}$ : Human resource management practices affect Competitive Advantage.

\section{Safety Culture}

Safety culture first appeared in the 1987 OECD Nuclear Agency report about the 1986 Chernobyl disaster (Cooper, 2000). During the last decade, the term has been used to describe a company atmosphere or culture where safety is understood and accepted as, number one priority to gain competitive advantage (Cullen, 1990). Aside from being a dominant characteristic of company culture, work safety must be in high-risk industries such as the construction industry where work safety culture is a sub-component of the company culture that includes individuals, jobs, and company features that affect and affect the health and safety of employees. Dutton et al. (1997) argue that risk prevention by investing in aspects of work safety can stimulate companies to create systems and even develop new technologies that support the establishment of a safety climate to create value for companies that will ultimately become a competitive advantage for companies. Besides, various studies have shown that safety culture as an organizational culture has been proven to influence job satisfaction and commitment as well as the impact on individual employee productivity and organizational performance (Chen et al., 2004; Randhawa \& Kaur, 2014). Therefore, the following hypothesis is proposed in this study:

H4: Work safety culture influences Competitive Advantage.

H5: Work safety culture influences Productivity.

\section{Productivity}

In the literature, employee productivity is defined as the relationship between output and input; between results and sacrifice (Kale \& Gawade, 2016). Labor productivity can be expressed as the amount of production for each unit of labor, or the number of hours worked for each unit product (Singh \& Mohanty, 2012). Koch and McGrath (1996) state that productivity is determined by the support of all company resources that can be measured in terms of effectiveness and efficiency, which is focused on aspects (1) the final results achieved, quality and quantity, (2) the length of time used to achieve the final results, and (3) optimal use of resources.

Thuo et al. (2018) state that increasing productivity aims to improve efficiency in producing goods or services. In other words, productivity expresses how to maximize the use of existing resources in producing goods and services. Productivity is a source that can provide a competitive advantage and long-term survival of a company. A company can increase its competitiveness by increasing productivity by adding added value to products/services produced better than other competitors. Thus, the following hypothesis is proposed in this study:

H6: Productivity effects on Competitive Advantage. 


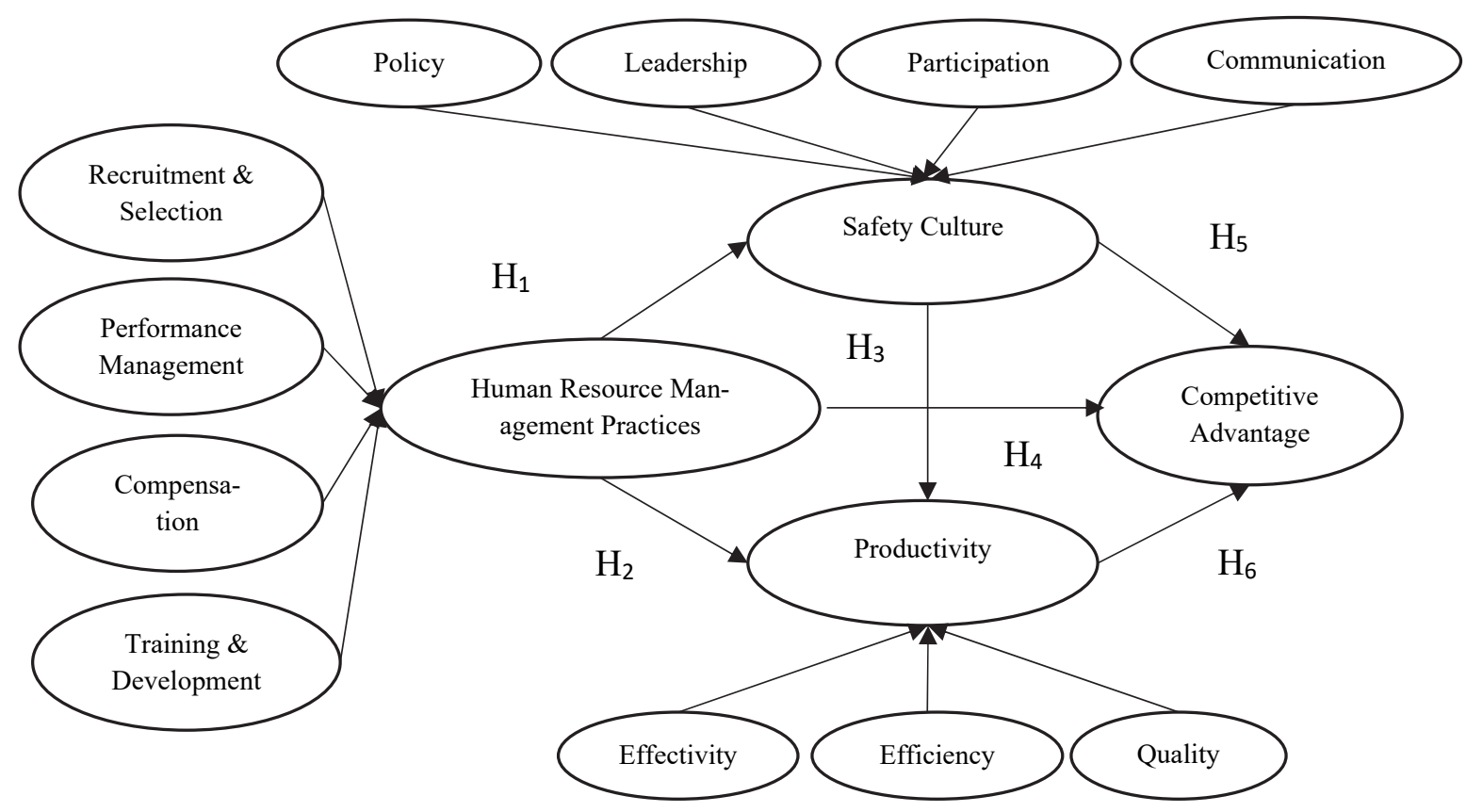

Fig. 3. The structure of the propsoed study

\section{Research Methods}

This research uses a quantitative approach to hypothesis testing and field study to test specific theories by examining the relationship between variables (Creswell, 2014). This research involves four variables, which are strategic human resource management, work safety culture, productivity, and competitive advantage. Measurements for each of these variables are explained below.

\subsection{Measurement}

Strategic human resource management, work safety culture, productivity, and competitive advantage are constructs that cannot be measured directly. Therefore, we need some indicators to be able to measure the contract (Wen et al., 2005). In this study, the indicators used to measure the extract were taken and developed from previous literature. Table 1 below shows the indicators used for each variable along with the reference sources used. The whole construct was measured using a 5-point liker scale ranging from strongly disagree (1) to strongly agree (5).

Table 1

Number of indicators and reference sources for construct measurements

\begin{tabular}{lcc}
\hline Construct & Indicators Number & Reference \\
\hline Human Resource Management Practices & 13 & Jackson et al. (2014) \\
Safety Culture & 18 & Muniz et al. (2017) \\
Productivity & 9 & Koch dan McGrath (2016) \\
Competitive Advantage & 4 & Barney (1991) \\
\hline
\end{tabular}

\subsection{Data Collection}

The population investigated in this study are construction companies in Indonesia that were active for at least one year. The population selection is based on data obtained from the Economic Census of the Central Statistics Agency (BPS) in 2017. The target population is top-level human resource management in construction companies in Indonesia, as many as 258,282 companies. Calculations were performed using the Slovin formula with a fault tolerance of $10 \%$ produce a total sample of 100 construction companies where one company is assumed to have 1 top-level management human resources department. The respondents in this study were 100 top-level management department of human resource management from 100 construction companies in Indonesia. The research instrument used in this study was to collect a lot of quantitative data efficiently (Sekaran \& Bougie, 2013). Data analysis in this study includes descriptive statistical analysis of the demographic profile of respondents, analysis of respondents' assessment of the variables studied, and testing of hypotheses and structural models. To meet the objectives of this study, the data analysis method used is Structural Equation Modeling (SEM). SEM was chosen because this method is a general statistical modeling technique and is widely used in behavioral sciences (Golob, 2003). All analyzes above have been carried out with the help of LISREL software. 


\subsection{Measurement}

Before multivariate data analysis can be performed, several assumptions of multivariate analysis must be tested. The sample size, variable scale, multicollinearity, multivariate normal distribution, and outliers are assumptions that need to be met (Hair et al. 1998; Fotopoulos \& Psomas, 2009; Lee et al. 2010). Regarding the sample size, Hair et al. (1998) state that, in conducting SEM, a sample size of 100 to 200 observations is sufficient and satisfying. In this study, sample size ( $\mathrm{n}=174)$, five-point Likert scale, skewness and kurtosis variables $(< \pm 1)$ are within acceptable limits, showing symmetry distribution (Fotopoulos \& Psomas, 2009; Lee et al. 2010). The correlation between independent variables is less than 0.9, a fact which suggests there is no multicollinearity problem (Hair et al. 1998; Fotopoulos and Psomas, 2009; Lee et al. 2010). As far as multivariate is normally distributed, skewness and kurtosis $(< \pm 1)$ and standardized residual $(< \pm 2.5)$ indicate that there are no indications of violations (Hair et al. 1998; Fotopoulos \& Psomas, 2009). Therefore, it can be said that the basic assumptions of multivariate analysis are fulfilled.

\subsection{Data analysis}

Structural Equation Modeling (SEM) is used to test the causal relationship between constructs. The researchers used a twostage modeling process in conducting SEM, as proposed by a number of researchers (e.g. Lin \& Lee, 2004; 2005; Hair et 1998) i.e. before testing the structural model, the measurement model must be tested using Confirmatory Factor Analysis (CFA) (Lee et al. 2010).

\section{Result}

\subsection{Measurement Model}

Confirmatory Factor Analysis (CFA) is used to assess the measurement model. The incremental fit index (IFI), non-normed fit index (NNFI), and comparative fit index (CFI) ratios are the three measures used to estimate the fit measurement model. The goodness of model fit for the measurement model in this study is shown in Table 2 and they are within acceptable limits. Therefore, it can be suggested that the measurement model has a good match with the data collected.

Table 2

The Goodness of Fit Measurement Model and Structural Model

\begin{tabular}{lccc}
\hline Goodness of Fit & $\begin{array}{c}\text { Measurement } \\
\text { Model }\end{array}$ & $\begin{array}{c}\text { Structural } \\
\text { Model }\end{array}$ & Value Received \\
\hline NNFI & 0.94 & 0.93 & $\geq 0.90$ (Hair et al., 2006) \\
CFI & 0.96 & 0.95 & $\geq 0.90$ (Hair et al., 2006) \\
IFI & 0.96 & 0.92 & $\geq 0.90$ (Hair et al., 2006) \\
\hline
\end{tabular}

The validity of the measurement model is assessed empirically by examining its convergent validity while the internal reliability of the measurement model is examined by performing a Cronbach alpha analysis (Meng et al. 2011; Hair et al. 1998; Liu et al. 2005; Foutopolos \& Psomas, 2009; 2010). The results are shown in Table 4. Convergent validity is confirmed because all loading factors are equal to or greater than 0.5 and statistically significant (Hair et al. 1998). The internal consistency of the construct in the measurement model or the reliability of the measurement model was tested using Cronbach alpha analysis. Most authors propose that alpha 0.60 or greater is considered reliable (Churchill, 1977; Hair et al. 1998). In this study, the Cronbach alpha value of the analysis results shows that all constructs are well above 0.60 . In other words, the measurement scale of this study is stable and consistent in measuring construct or reliable.

Table 3

Construction Validity and Reliability

\begin{tabular}{|c|c|c|c|c|c|}
\hline No. & Latent Variable & Dimension & Indicator & Standardized Factor Loading & Cronbach Alpha \\
\hline \multirow[t]{18}{*}{1.} & \multirow[t]{18}{*}{ Safety Culture } & \multirow[t]{3}{*}{ Policy } & Regulation & 0.91 & \multirow[t]{18}{*}{0.976} \\
\hline & & & Coordination & 0.87 & \\
\hline & & & Commitment & 0.89 & \\
\hline & & \multirow[t]{5}{*}{ Leadership } & Example & 0.92 & \\
\hline & & & Inspiration & 0.91 & \\
\hline & & & Support & 0.93 & \\
\hline & & & System & 0.94 & \\
\hline & & & Evaluation & 0.91 & \\
\hline & & \multirow[t]{6}{*}{ Participation } & Voluntary & 0.51 & \\
\hline & & & Assisting & 0.78 & \\
\hline & & & Discussing & 0.86 & \\
\hline & & & Inspecting & 0.91 & \\
\hline & & & Correcting & 0.89 & \\
\hline & & & Delivering & 0.79 & \\
\hline & & \multirow[t]{4}{*}{ Communication } & Meeting & 0.65 & \\
\hline & & & Procedure & 0.86 & \\
\hline & & & Information & 0.93 & \\
\hline & & & Manual Instruction & 0.86 & \\
\hline
\end{tabular}


Table 3

Construction Validity and Reliability (Continued)

\begin{tabular}{|c|c|c|c|c|c|}
\hline No. & Latent Variable & Dimension & Indicator & $\begin{array}{c}\text { Standardized Factor } \\
\text { Loading }\end{array}$ & Cronbach Alpha \\
\hline \multirow[t]{13}{*}{2.} & \multirow{13}{*}{$\begin{array}{l}\text { Human } \\
\text { resource } \\
\text { management prac- } \\
\text { tices }\end{array}$} & \multirow[t]{3}{*}{ Recruitment } & Suitability & 0.71 & \multirow[t]{13}{*}{0.976} \\
\hline & & & Potential & 0.67 & \\
\hline & & & Internal Candidate & 0.53 & \\
\hline & & Performance & Objective & 0.62 & \\
\hline & & \multirow[t]{2}{*}{ Management } & Development & 0.72 & \\
\hline & & & Company progress & 0.73 & \\
\hline & & \multirow[t]{3}{*}{ Compensation } & Salary & 0.54 & \\
\hline & & & Bonus & 0.70 & \\
\hline & & & Incentive & 0.80 & \\
\hline & & \multirow{4}{*}{$\begin{array}{l}\text { Training \& } \\
\text { development }\end{array}$} & Training & 0.75 & \\
\hline & & & Follow up & 0.75 & \\
\hline & & & Planning & 0.69 & \\
\hline & & & Periodic & 0.79 & \\
\hline \multirow[t]{9}{*}{3.} & \multirow[t]{9}{*}{ Productivity } & \multirow[t]{3}{*}{ Effectivity } & Professionality & 0.57 & \multirow[t]{9}{*}{0.976} \\
\hline & & & Responsibility & 0.63 & \\
\hline & & & According to the procedure & 0.63 & \\
\hline & & \multirow[t]{3}{*}{ Efficiency } & On-time & 0.56 & \\
\hline & & & Organized & 0.64 & \\
\hline & & & Cost & 0.55 & \\
\hline & & \multirow[t]{3}{*}{ Quality } & Knowledge & 0.57 & \\
\hline & & & Ability & 0.54 & \\
\hline & & & Outcome & 0.74 & \\
\hline \multirow[t]{4}{*}{4.} & \multirow{4}{*}{$\begin{array}{l}\text { Competitive } \\
\text { vantage }\end{array}$} & & Effective and Efficiency & 0.69 & \multirow[t]{4}{*}{0.977} \\
\hline & & & Rare & 0.67 & \\
\hline & & & Unique & 0.87 & \\
\hline & & & Irreplaceable & 0.94 & \\
\hline
\end{tabular}

\subsection{Structural Model}

Structural models differ from measurement models in terms of the relationship between latent constructs and measured variables (Hair et al. 2005). Fig. 2 shows the results of the estimation of the structure of the model. According to the Chi-square index $(\mathrm{x} 2$ test statistics $/ \mathrm{df}=4.63)$ and other indices $(\mathrm{NFI}=0.93, \mathrm{NNFI}=0.93$, and $\mathrm{IFI}=0.95)$, the structural model is suitable, as shown in Table 2. On picture. 2, it is shown that the six direct path coefficients are statistically significant. Thus, hypotheses $1,2,3$, and 5 were accepted. Two of the 6 hypothetical pathways, namely strategic human resource management to competitive advantage $\left(\mathrm{H}_{4}\right)$ and productivity to competitive advantage $\left(\mathrm{H}_{6}\right)$ are not significantly accepted in the path coefficient statistics. Table 4 explains the direct effects of various determinants of competitive advantage. In terms of direct relationships, safety culture $(0.78)$ has the greatest effect. Whereas in indirect relationships, human resource management practices have the greatest effect $(0.89)$ followed by productivity $(0.65)$.

Table 4

Direct Effects of Competitive Advantage

\begin{tabular}{|c|c|c|}
\hline Path & Estimates & T value \\
\hline Human resource management practices $\rightarrow$ Safety culture & 0.89 & 9.59 \\
\hline Human resource management practices $\rightarrow$ Productivity & 0.65 & 5.48 \\
\hline Human resource management practices $\rightarrow$ Competitive advantage & 0.53 & 1.81 \\
\hline Safety culture $\rightarrow$ Productivity & 0.32 & 2.68 \\
\hline Safety culture $\rightarrow$ Competitive advantage & 0.78 & 3.09 \\
\hline Productivity $\rightarrow$ Competitive advantage & -0.66 & -2.11 \\
\hline
\end{tabular}

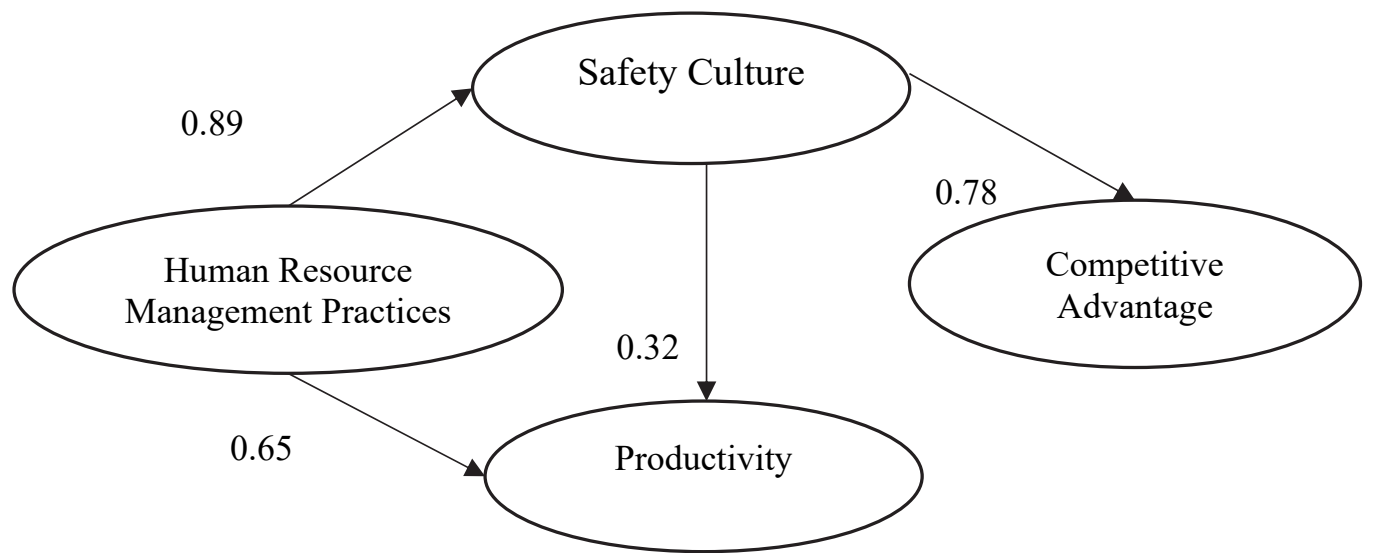

Fig. 4. The results of structural model 


\section{Managerial Implications and Conclusions}

This paper has discussed the determinants of competitive advantage in the construction industry in Indonesia through structural equation modeling (SEM). 174 construction companies in Indonesia were surveyed to test the structural model. The results have shown that safety culture had a direct and positive effect on competitive advantage. Furthermore, this study also found that human resource management practices had an indirect effect on competitive advantage. These findings are supported by research findings Rui et al. (2017) and Ellitan (2004). Regarding the effect of safety culture, the findings are supported by Rechenthin (2004) and Fernández-Muñiz et al. (2009). Meanwhile, the effect of human resource management practices on productivity was confirmed by Pahos and Galanaki (2018) and Xiu et al. (2017) and the effect of safety culture on productivity is confirmed by Lamm et al. (2007) and Tappura et al. (2015). The results of this study suggest several important implications for competitive advantage in the construction industry in Indonesia. The significant direct effect of safety culture reflects the importance of culture in the company. In response to this finding, Fernández-Muñiz et al. (2009) suggested that the company had a clear policy regarding employee safety, also, the leadership must hold strong commitments related to the policy and should be an example in the implementation of the policy. Sampson et al. (2014) confirm that employee participation and communication between management and workers are also important in safety culture concerning company competitive advantage. Human resource management practices indirectly affect competitive advantage and directly influence safety culture and productivity. According to Chan and Mak (2012), the results of loading factors from the confirmatory factor analysis (CFA) provide useful information for construction companies to establish a safety culture through human resource management practices. The results revealed that the attributes that need to be considered are (1) recruitment and selection, (2) performance management, (3) compensation, and (4) training and development. Thus, this information can be utilized by managers to pay attention to the attributes of performance management as the highest factor in shaping safety culture (Zacharatos et al., 2005). This study found some interesting findings, but this finding also has some limitations. First, this study uses cross-sectional data and it is difficult to determine the link cross-time time series variables (Lee et al. 2010). Therefore, the results of the study may be different if done at a later time. Secondly, the limitations of sample size and convenience sampling methods implied that the findings could not be generalized to all construction companies in Indonesia. Therefore, researchers propose to conduct longitudinal research with more samples and improve sampling methods so that the results of the study can be generalized. Finally, researchers also suggest entering company performance variables in further research because company performance is a benchmark of competitive advantage as shown by research conducted in the manufacturing industry (Schroeder et al., 2002) and in mining industry (Tuck et al., 2005).

\section{Acknowledgement}

This research was supported by Mercu Buana University. We also thank Dudi Permana, Sik Sumaedi and I Gede Mahatma Yuda Bakti from the Indonesian Institute of Sciences (LIPI) who were involved in this research.

\section{References}

Barney, J. B. (1991). Firm resources and sustained competitive advantage. Journal of Management, 17(1), 99-120.

Becker, B., \& Gerhart, B. (1996). The impact of human resource management on organizational performance: Progress and prospects. Academy of Management Journal, 39(4), 779-801.

Chan, S. C. H., \& Mak, W. (2012). High performance human resource practices and organizational performance. Journal of Chinese Human Resources Management, 3(2), 136-150. https://doi.org/10.1108/20408001211279238

Chen, Y. Y. M., Accardi, A. J., Kiciman, E., Patterson, D. A., Fox, A., \& Brewer, E. A. (2004). Path-based failure and evolution management (pp. 23-23). University of California, Berkeley.

Chuang, C. H., Chen, S. J., \& Chuang, C. W. (2013). Human resource management practices and organizational social capital: The role of industrial characteristics. Journal of Business Research, 66(5), 678-687.

Churchill, G. A. (1979). A paradigm for developing better measures of marketing constructs. Journal of Marketing Research, 19, 491-504.

Cooper, M. D. (2000). Towards a model of safety culture. Safety science, 36(2), 111-136.

Clarke, S. (1999). Perceptions of organizational safety: implications for the development of safety culture. Journal of Organizational Behavior, 20, 185-98.

Creswell, J. W. (2014). Research Design Pendekatan Metode Kualitatif, Kuantitatif, dan Campuran. Yogyakarta: Pustaka Pelajar.

Cullen, P. (1990). The turbulent boundary between water science and water management. Freshwater Biology, 24(1), 201209.

Delery, J.E., \& Doty, D.H. (1996). Modes of theorizing in strategic human resource management: Tests of universalistic, contingency, and configurational performance predictions. Academy of Management Journal, 39(4), 802-835.

Dutton, J. E., Ashford, S. J., O’neill, R. M., Hayes, E., \& Wierba, E. E. (1997). Reading the wind: How middle managers assess the context for selling issues to top managers. Strategic Management Journal, 18(5), 407-423.

Ellitan, L. (2004). Praktik-Praktik Pengelolaan Sumber Daya Manusia Dan Keunggulan Kompetitif Berkelanjutan. Jurnal Manajemen Dan Kewirausahaan, 4(2), 65-76. https://doi.org/10.9744/jmk.4.2.pp. 65-76

Fernández-Muñiz, B., Montes-Peón, J. M., \& Vázquez-Ordás, C. J. (2009). Relation between occupational safety management and firm performance. Safety Science, 47(7), 980-991. https://doi.org/10.1016/j.ssci.2008.10.022 
Fotopoulos, C. B., \& Psomas, E. L. (2009). The impact of "soft" and "hard" TQM Elements on quality management results. International Journal of Quality and Reliability Management, 26, 150-163.

Foutopolos, C. B., \& Psomas, E. L. (2010). The structural relationships between TQM factors and organizational performance. The TQM Journal, 22, 539-552.

Golob, T.F. (2003). Structural equation modeling for travel behaviour research. Transportation Research, 37, 1-25.

Gubler, T., Larkin, I., \& Pierce, L. (2018). Doing well by making well: The impact of corporate wellness programs on employee productivity. Management Science, 64(11), 4967-4987.

Guthrie, J., \& Datta, D. (2004, August). HRM and firm performance: Peeling back the onion. In Academy of Management Meeting in New Orleans (pp. 6-11).

Guzzo, R. A., Jette, R. D., \& Katzell, R. A. (1985). The effects of psychologically based intervention programs on worker productivity: A meta-analysis. Personnel Psychology, 38(2), 275-291.

Hair, J. F. Jr. Black, W. C., Babin, B. J. Anderson, R. E. \& Tatham, R. L. (2006). Multivariate data analysis (6th Ed.). New Jersey: Prentice Hall.

Hair, J. F., Anderson, R. E., Tatham, R. L., \& Black, W. C. (1998). Multivariate data analysis. $5^{\text {th }}$ ed., Prentice-Hall.

Handoko, B. L., Aryanto, R., \& So, I. G. (2015). The impact of enterprise resources system and supply chain practices on competitive advantage and firm performance: Case of Indonesian companies. Procedia Computer Science, 72, $122-128$.

Huselid, M. A. (1995). The impact of human resource management practices on turnover, productivity, and corporate financial performance. Academy of Management Journal, 38(3), 635-672.

Kale, A. P., \& Gawade, S. N. (2016). Studies on nanoparticle induced nutrient use efficiency of fertilizer and crop productivity. Green Chemistry Technical Letter, 2, 88-92.

Koch, M. J., \& McGrath, R. G. (1996). Improving labor productivity: Human resource management policies do matter. Strategic Management Journal, 17(5), 335-354.

Lamm, F., Massey, C., \& Perry, M. (2007). Is there a link between workplace health and safety and firm performance and [roductivity. New Zealand Journal of Employment Relations, 32(1), 72-86.

Lee, V. H., Ooi, K. B., Tan, B. I., \& Chong, A. Y. L. (2010). A structural analysis of the relationship between TQM practices and product innovation. Asian Journal of Technology Innovation, 18, 73-96.

Meng, S. M., Liang, G. S., \& Yang, S. H. (2011). The relationships of cruise image, perceived value, satisfaction, and postpurchase behavioral intention on Taiwanese tourists. African Journal of Business Management 5(1), 19-29.

Pahos, N., \& Galanaki, E. (2018). Staffing practices and employee performance: the role of age. Evidence-Based HRM.

Ployhart, R. E., Van Iddekinge, C. H., \& MacKenzie Jr, W. I. (2011). Acquiring and developing human capital in service contexts: The interconnectedness of human capital resources. Academy of management journal, 54(2), 353-368.

Randhawa, G., \& Kaur, K. (2014). Organizational climate and its correlates. Journal of Management Research, 14(1), 25-40.

Rechenthin, D. (2004). Project safety as a sustainable competitive advantage. Journal of Safety Research, 35(3), 297-308.

Rui, H., Zhang, M., \& Shipman, A. (2017). Chinese expatriate management in emerging markets: A competitive advantage perspective. Journal of International Management, 23(2), 124-138. https://doi.org/10.1016/j.intman.2017.01.002

Sampson, J. M., DeArmond, S., \& Chen, P. Y. (2014). Role of safety stressors and social support on safety performance. Safety Science, 64, 137-145. https://doi.org/10.1016/j.ssci.2013.11.025

Schroeder, R. G., Bates, K. A., \& Junttila, M. A. (2002). A resource-based view of manufacturing strategy and the relationship to manufacturing performance. Strategic Management Journal, 23(2), 105-117.

Singh, R., \& Mohanty, M. (2012). Impact of training practices on employee productivity: A comparative study. Interscience Management Review (IMR), 2(2), 74.

Tappura, S., Sievänen, M., Heikkilä, J., Jussila, A., \& Nenonen, N. (2015). A management accounting perspective on safety. Safety Science, 71(PB), 151-159. https://doi.org/10.1016/j.ssci.2014.01.011

Thuo, R., Senaji, T., \& Kirimi, E. (2018). Influence of strategic human resource management (SHRM) practices on employee productivity: A case of the energy sector in Kenya. International Academic Journal of Human Resource and Business Administration, 3(2), 430-451.

Tuck, J., Lowe, J., \& McRae-Williams, P. (2005). Managing community relationships, reputation and sustaining competitive advantage: the case of mining towns. Centre for Sustainable Regional Communities, La Trobe University.

Wen, C. H., Lan, L. W., \& Cheng, H. L. (2005). Structural equation modeling to determine passenger loyalty toward intercity bus services. Transportation Research Record, 1927(1), 249-255.

World Economic Forum., (2017). Global Competitiveness Index. Retrieved 24 Juni 2018, from https://widgets.weforum.org/global-competitiveness-report-2017.html

Xiu, L., Liang, X., Chen, Z., \& Xu, W. (2017). Strategic flexibility, innovative HR practices, and firm performance: A moderated mediation model. Personnel Review, 46(7), 1335-1357. https://doi.org/10.1108/PR-09-2016-0252

Zacharatos, A., Barling, J., \& Iverson, R. D. (2005). High-performance work systems and occupational safety. Journal of Applied Psychology, 90(1), 77-93. https://doi.org/10.1037/0021-9010.90.1.77

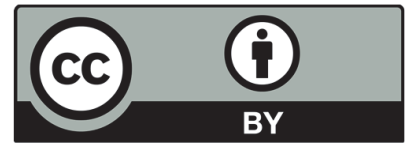

(C) 2020 by the authors; licensee Growing Science, Canada. This is an open access article distributed under the terms and conditions of the Creative Commons Attribution (CC-BY) license (http://creativecommons.org/licenses/by/4.0/). 